\title{
PENAMPILAN PERTUMBUHAN DAN HASIL DUA BELAS GENOTIPE GANDUM (Triticum aestivum L.) DITANAM di DATARAN RENDAH DALAM RANGKA MENCARI CALON TETUAADAPTIFDATARAN RENDAH
}

\section{Yosep Chandra Puspita ${ }^{1}$, Nugraheni Widyawati ${ }^{2}$ Djoko Murdono $^{2}$}

Diterima 26 Juni 2012, disetujui28 Juni 2013

\begin{abstract}
In order to looking for some parent materials of wheat adaptif tropical lowland, there have been done an experimental field to study the phenotype of twelve wheat genotype (Triticum aestivum L.) that cultivated in lowland from June 17, until October 17, 2011, at a field of PT. Sango Ceramics Indonesia, Mangkang -Wonosari, Ngalian, Semarang, Central of Java, about 13 meter above the sea level. The purpose of these research were to observe the phenotype performance of twelve wheat genotypes at tropical lowland and to determine the wheat genotype that are potential to be observe as parent materials which adaptif in tropical lowland. The research used Randomized Block Design with twelve treatments and three replications. The treatments were 1) OASIS/SKAUZ//4*BCN, 2) HP 1744, 3) LAJ3302/MO88, 4) RABE/MO88, 5) H-21, 6) G-21, 7) G-18, 8) Menemen, 9) Basribey, 10) Alibey, 11) Selayar and 12) Dewata. The result of this research were the growth and yield performance of twelve wheat genotypes at tropical lowland $13 \mathrm{~m}$ above the sea level were different in crop height, number of tiller, 1000 grain weight, number of grain/spikelet, grain weight of forth line but there werenot different in flowering time, harvest time and one liter weight of grain. The wheat genotypes that are potential performance to be observed as parent materials of tolerant lowland wheat are Basribey and Menemen genotype.
\end{abstract}

Keywords: wheat genotype, Fenotype, tropical lowland.

\section{PENDAHULUAN}

Gandum adalah tanaman terbesar ketiga di dunia setelah jagung dan padi, serta menjadi sumber karbohidrat esensial bagi jutaan manusia. Gandum dapat tumbuh dalam rentang lingkungan yang cukup luas, tetapi pada umumnya di negara sentra produksi gandum, periode pengisian biji (grain filling) terjadi ketika kelembaban tanah menurun dan suhu udara meningkat ( Asseng et al., 2010). Pengembangan tanaman gandum di Indonesia sebagian besar dilakukan di wilayah dataran tinggi, sementara lahan dataran rendah sebenarnya juga sangat potensial untuk pengembangan tanaman gandum tropis. Namun hal ini baru bisa terjadi apabila ditemukan varietas gandum yang mampu beradaptasi di daerah dataran rendah tropis yang dicirikan oleh suhu udara relatif tinggi dan peluang mengalami periode kekeringan cukup besar.

Ghazi (2012) menyebutkan bahwa cekaman suhu tinggi dan kekeringan adalah faktor lingkungan yang sangat penting yang berdampak pada laju

1. Alumni Fakultas Pertanian dan Bisnis Universitas Kristen Satya Wacana.

2. Staff Pengajar Fakultas Pertanian dan Bisnis Universitas Kristen Satya Wacana, email:heniwidya@gmail.com J1. Diponegoro 52-60 Salatiga 50711 
pertumbuhan dan perkembangan tanaman gandum. Dalam kondisi cekaman lingkungan seperti ini maka siklus hidup tanaman gandum hidupnya akan lebih pendek dibandingkan dengan siklus di lingkungan yang normal, akibatnya akumulasi asimilat akan berlangsung dalamjumlah hari yang lebih sedikit, sehingga hasil gandum lebih rendah. Punia et al., (2011) menyebutkan bahwa cekaman suhu tinggi yang dicirikan oleh suatu peningkatan suhu rata-rata selama antesis dan pengisian biji yang menyebabkan percepatan kemasakan biji, merupakan hambatan utama dalam produksi gandum di wilayah arid dan semi arid. Hasil penelitian Gill (2009) menjelaskan bahwa GDD (growing degree days) adalah kriteria seleksi yang efektif untuk menapis galur gandum thermotoleran.

Nur et al., (2010) mengatakan bahwa setiap genotipe memiliki kemampuan yang berbeda dalam mengatasi cekaman suhu tinggi. Hal ini berarti bahwa ada kemungkinan genotip yang mampu beradaptasi dalam cekaman suhu tinggi dan apabila bisa ditemukan maka dapat dikembangkan varietas gandum yang mampu beradaptasi di wilayah dataran rendah yang memiliki karakter cekaman suhu tinggi. Jika upaya itu berhasil maka penanaman gandum di Indonesia akan semakin luas wilayahnya. Langkah awal yang dapat dilakukan adalah melakukan seleksi terhadap genotipe gandum terutama yang potensial untuk beradaptasi di dataran rendah tropis sebagai calon tetua yang bisa dikembangkan di dataran rendah tropis melalui serangkaian uji adaptasi dan seleksi.

Perkembangan varietas yang mempunyai potensi hasil tinggi digabungkan dengan kemampuan adaptasi yang luas merupakan tujuan penting dalam pemuliaan tanaman (Das et al., 2011). Keberadaan genotip berinteraksi dengan lingkungan berperan penting dalam menentukan penampilan materi genetik yang diuji pada lokasi-lokasi dan tahun yang berbeda, dan mempengaruhi proses seleksi (Purchase et al., 2000). Estimasi interaksi antara genotipe dan lingkungan akan membantu pemulia tanaman untuk memutuskan strategi pemuliaan, menghasilkan adaptasi spesifik atau umum, tergantung pada stabilitas penampilan hasil dibawah kondisi rentang lingkungan terbatas atau rentang yang luas.

Sejauh ini belum banyak hasil penelitian yang bertujuan untuk menemukan tetua gandum adaptif dataran rendah tropis khususnya di wilayah Nusantara. Tahap awal yang bisa dilakukan antara lain adalah penelitian lapangan yang menganalisis fenotipe sejumlah genotype gandum yang ditanam di dataran rendah.

\section{TUJUAN PENELITIAN}

Berdasarkan latar belakang yang telah dikemukakan, maka penelitian ini bertujuan:

1. Mengetahui penampilan pertumbuhan dan hasil dari dua belas genotipe gandum yang ditanam di dataran rendah tropis.

2. Menentukan genotipe gandum yang potensial untuk diuji kembali di dataran rendah sebagai calon tetua adaptif dataran rendah.

\section{METODE PENELITIAN}

Penelitian dilaksanakan pada tanggal 17 Juni 2011 sampai 17 Oktober 2011 di lahan milik PT Sango Ceramics Indonesia, Jalan Raya Mangkang KM 14, Wonosari, Ngalian, Semarang, provinsi Jawa Tengah. Lokasi penelitian terletak pada ketinggian tempat \pm 13 meter dpl. Rancangan percobaan yang digunakan dalam penelitian ini adalah Rancangan Acak Kelompok (RAK) dengan 12 perlakuan yang berupa genotip gandum dan diulang tiga kali. Genotip gandum yang diuji adalah: 


\begin{tabular}{|c|c|}
\hline $\begin{array}{c}\text { KODE } \\
\text { GENOTIP }\end{array}$ & PERLAKUAN GENOTIPE \\
\hline A & $\begin{array}{l}\text { OASIS/SKAUZ//4*BCN } \\
\text { CMSS93Y04054M-1M-OY-OHTY }\end{array}$ \\
\hline B & HP1744-01ND \\
\hline $\mathrm{C}$ & $\begin{array}{l}\text { LAJ3302/2*MO88 } \\
\text { CMSS92Y0164T-10Y-10M-10Y-010Y-5M-0Y-OHTY }\end{array}$ \\
\hline $\mathrm{D}$ & $\begin{array}{l}\text { RABE/2*MO88 } \\
\text { CMSS92Y01634T-18Y-010M-010Y-010Y-1M-0Y-OHTY }\end{array}$ \\
\hline $\mathrm{E}$ & $\mathrm{H}-21$ \\
\hline $\mathrm{F}$ & G-21 \\
\hline G & G-18 \\
\hline $\mathrm{H}$ & Menemen \\
\hline I & Basribey \\
\hline $\mathrm{J}$ & Alibey \\
\hline $\mathrm{K}$ & Selayar \\
\hline $\mathrm{L}$ & Dewata \\
\hline
\end{tabular}

Penampilan pertumbuhan dan perkembangan tanaman diamati berdasarkan tinggi tanaman, jumlah anakan, umur berbunga dan umur panen. Hasil tanaman diamati berdasarkan jumlah biji per malai yang berisi, jumlah biji per malai yang tidak terbentuk, jumlah malai per $\mathrm{m}^{2}$, panjang malai, bobot 1 liter biji, bobot 4 baris tengah, bobot 1000 butir.

Data dari hasil pengamatan utama dianalisis dengan menggunakan metode sidik ragam. Untuk mengetahui pengaruh antar perlakuan digunakan Uji Beda Nyata Jujur (BNJ) dengan selang kepercayaan 95 persen. Untuk mengetahui keeratan hubungan antar komponen pengamatan dengan hasil gandum yang diwakili dari parameter bobot 4 baris tengah, dianalisis dengan Korelasi-Regresi. Nilai korelasi semakin mendekati 1,0 artinya hubungan antara parameter tersebut dengan hasil gandum semakin erat. Persentase pembobotan dihitung dari pembandingan nilai korelasi tiap parameter dengan nilai korelasi totalnya. Skor total dihitung dengan menjumlah skor dari semua parameter yang diuji dari setiap genotipe.

\section{HASIL dan PEMBAHASAN}

Selama penelitian berlangsung, diamati keadaan suhu udara, kelembaban udara dan curah hujan lokasi penelitian untuk memberikan gambaran tentang kondisi lingkungan di lokasi penelitian. Hasil pencatatan suhu udara, kelembaban udara dan curah hujan disajikan dalam Tabel 1.

Ghazi (2012) menyebutkan bahwa untuk menghasilkan pertumbuhan gandum yang baik dan hasil yang tinggi, diperlukan kondisi suhu lingkungan optimum yaitu $18^{\circ} \mathrm{C}-24^{\circ} \mathrm{C}$. Acevedo et al., (1991 dalam Ghazi, 2012) menyebutkan bahwa setiap peningkatan $1^{\circ} \mathrm{C}$ dari suhu udara dari $17^{\circ} \mathrm{C}$ hingga $24^{\circ} \mathrm{C}$ pada fase pengisian biji dapat menurunkan bobot biji gandum sekitar 4 persen. Pada Tabel 1 menunjukkan bahwa selama penelitian ini berlangsung, dua belas 
Tabel 1. Tabel suhu maksimum, suhu minimum, kelembaban udara dan curah hujan selama penelitian

\begin{tabular}{lcccc}
\hline \multicolumn{1}{c}{ Bulan } & Suhu Maks. $\left({ }^{\circ} \mathrm{C}\right)$ & Suhu Min. $\left({ }^{\circ} \mathrm{C}\right)$ & $\begin{array}{c}\text { Kelembaban } \\
\text { udara. }(\%)\end{array}$ & $\begin{array}{c}\text { Curah Hujan } \\
(\mathrm{mm})\end{array}$ \\
\hline Juli 2011 & 32,5 & 24,2 & 70 & 73 \\
Agustus 2011 & 33,2 & 23,7 & 65 & 0 \\
September 2011 & 34 & 24,2 & 66 & 74 \\
Oktober 2011 & 34,1 & 25,1 & 66 & 53 \\
\hline \multicolumn{7}{c}{ Total } & & 200 \\
\hline
\end{tabular}

genotip gandum yang diuji tersebut tumbuh pada lingkungan yang suhu udaranya melebihi rentang kebutuhan untuk pertumbuhan optimumnya, karena suhu udara di lokasi penelitian adalah $23,7^{\circ} \mathrm{C}$ hingga $34,1^{\circ} \mathrm{C}$. Hal ini berarti bahwa dua belas genotip gandum yang diuji tersebut mengalami tekanan suhu tinggi.

Kelembaban udara selama penelitian berlangsung, secara umum termasuk kategori sedang. Tanaman gandum tumbuh lebih baik pada lingkungan yang kelembaban udaranya rendah karena kelembaban yang tinggi menyebabkan serangan jamur pada spikeletnya. Rossi et al., (2001) menyebutkan bahwa pada kondisi kelembaban tinggi maka infeksi Fusarium graminearum pada spikelet tanaman gandum bisa mencapai 73,5 persen.

Dari data curah hujan selama penelitian, nampaknya lebih rendah dari yang diperlukan yaitu $350 \mathrm{~mm}-1250 \mathrm{~mm}$ selama siklus hidupnya (Tentrirawe dan Pabbage, 2010). Untuk menghindari kekeringan dan hilangnya semua materi percobaan maka tanaman gandum yang diuji mendapatkan pengairan tambahan secara teratur. Hal ini berarti bahwa dua belas genotip gandum yang diuji tersebut tidak mengalami tekanan kekeringan selama siklus hidupnya, melainkan hanya mengalami tekanan suhu tinggi. Prasad $e t$ al (2011) menyebutkan bahwa tekanan suhu tinggi dan kekeringan adalah dua faktor lingkungan yang sangat penting dalam mempengaruhi pertumbuhan, perkembangan dan hasil tanaman. Kedua tekanan lingkungan ini biasanya terjadi dalam suatu kombinasi. Selain itu Ghazi (2012) juga menyebutkan bahwa kekeringan dan tekanan suhu tinggi adalah dua faktor lingkungan yang sangat penting dalam mempengaruhi laju pertumbuhan dan perkembangan tanaman.

\section{Penampilan Pertumbuhan dan Perkem- bangan Tanaman}

Penampilan pertumbuhan dan perkembangn tanaman dari dua belas genotip gandum yang diuji, disajikan dalam Tabel 2. Dalam tabel tersebut terlihat bahwa genotipe berkode L yaitu Dewata tanamannya relatif lebih tinggi dari genotip yang lain, yaitu 54,49 cm meskipun tidak berbeda nyata dengan tinggi tanaman dari gernotip berkode C,E,G dan I. Dari aspek jumlah anakan yang tumbuh, tampak bahwa variasinya antara 2,63 hingga 6,37 dan yang potensial membentuk anakan lebih banyak adalah genotip berkode A sedangkan yang relatif sedikit jumlah anakannya adalah genotip berkode J. Dari aspek perkembangan tanaman, ternyata duabelas genotip gandum yang diuji tersebut tidak berbeda nyata umur berbunga dan umur panennya. Hal ini menunjukkan bahwa sebenarnya dari aspek lamanya waktu untuk berlangsungnya pengisian biji antar genotip yang diuji tersebut tidak berbeda.

Hasil penelitian Nur et al., (2010) menunjukkan bahwa perubahan lingkungan tumbuh dari dataran tinggi ke dataran rendah pada lingkungan tropika basah menyebabkan terjadinya penurunan daya berkecambah benih, penurunan tinggi tanaman dan penurunan jumlah anakan produktif dari setiap genotipe gandum yang diuji. Tinggi tanaman dan jumlah anakan setiap genotip di dataran tinggi tidak 
Tabel 2. Penampilan pertumbuhan dari dua belas genotipe gandum yang ditanam di dataran rendah tropis

\begin{tabular}{|c|c|c|c|c|c|c|c|c|}
\hline \multirow{3}{*}{$\begin{array}{c}\text { Kode } \\
\text { Genotipe } \\
\text { A }\end{array}$} & \multicolumn{8}{|c|}{ Parameter } \\
\hline & \multicolumn{2}{|c|}{$\begin{array}{l}\text { Tinggi } \\
\text { tanaman } \\
(\mathrm{cm})\end{array}$} & \multicolumn{2}{|c|}{ Jumlah anakan } & \multicolumn{2}{|c|}{$\begin{array}{c}\text { Umur } \\
\text { berbunga } \\
\text { (hari) }\end{array}$} & \multicolumn{2}{|c|}{$\begin{array}{l}\text { Umur panen } \\
\text { (hari) }\end{array}$} \\
\hline & 46,34 & $\mathrm{AB}$ & 6,37 & B & 71,00 & A & 99,67 & A \\
\hline B & 44,33 & $\mathrm{AB}$ & 5,13 & $\mathrm{AB}$ & 67,00 & A & 96,00 & A \\
\hline $\mathrm{C}$ & 47,47 & $\mathrm{ABC}$ & 5,13 & $\mathrm{AB}$ & 68,33 & A & 97,67 & A \\
\hline $\mathrm{D}$ & 45,93 & $\mathrm{AB}$ & 5,73 & $\mathrm{AB}$ & 66,67 & A & 95,67 & A \\
\hline $\mathrm{E}$ & 48,02 & $\mathrm{ABC}$ & 3,13 & $\mathrm{AB}$ & 68,33 & A & 98,00 & A \\
\hline $\mathrm{F}$ & 46,81 & $\mathrm{AB}$ & 4,60 & $\mathrm{AB}$ & 66,00 & A & 95,00 & A \\
\hline $\mathrm{G}$ & 49,86 & $\mathrm{BC}$ & 3,23 & $\mathrm{AB}$ & 68,00 & A & 97,00 & A \\
\hline $\mathrm{H}$ & 42,93 & $\mathrm{AB}$ & 4,53 & $\mathrm{AB}$ & 65,67 & A & 95,00 & A \\
\hline I & 49,26 & $\mathrm{BC}$ & 4,87 & $\mathrm{AB}$ & 66,00 & A & 96,00 & A \\
\hline $\mathrm{J}$ & 40,42 & $\mathrm{~A}$ & 2,63 & $\mathrm{~A}$ & 70,00 & A & 99,00 & $\mathrm{~A}$ \\
\hline K & 44,24 & $\mathrm{AB}$ & 5,23 & $\mathrm{AB}$ & 67,00 & A & 96,67 & A \\
\hline $\mathrm{L}$ & 54,49 & $\mathrm{C}$ & 4,00 & $\mathrm{AB}$ & 69,67 & A & 98,67 & A \\
\hline
\end{tabular}

Keterangan: Angka yang diikuti oleh huruf yang sama menunjukkan tidak berbeda nyata antar perlakuan sedangkan angka yang diikuti huruf yang berbeda menunjukkan perbedaan yang nyata antar perlakuan.

memperlihatkan pengaruh yang nyata, namun pada dataran rendah baik tinggi tanaman dan jumlah anakan setiap genotipe memberikan respon yang berbeda (Nur et al., 2010).

Hasil penelitian Nur et al., (2010) dari parameter tinggi tanaman genotip Selayar yang ditanam di ketinggian $<400 \mathrm{~m} \mathrm{dpl}$, adalah $58,5 \mathrm{~cm}$ sedangkan Dewata adalah $50,8 \mathrm{~cm}$. Jika dibandingkan dengan hasil uji genotipe dalam penelitian ini, maka pencapaian tinggi tanamannya relatif lebih rendah yaitu 44,24 cm untuk Selayar dan 54,49 $\mathrm{cm}$ untuk Dewata. Pertumbuhan tinggi tanaman secara umum dipengaruhi oleh aktivitas auksin yang terdapat di titik tumbuh apical. Auksin merupakan hormon yang peka terhadap radiasi matahari, yaitu aktivitasnya dalam memacu pembelahan dan pembesaran sel akan terhambat justru pada kondisi menerima intensitas matahari melebihi optimumnya. Penerimaan intensitas radiasi matahari di dataran rendah relatif lebih tinggi dibandingkan dengan di dataran tinggi. Diduga lokasi tempat penelitian ini (elevasi sekitar 13 meter dpl.) intensitas radiasi mataharinya lebih tinggi, sehingga terjadi gangguan terhadap aktivitas hormon auksin untuk memacu pertumbuhan tinggi tanaman.

Dalam hal jumlah anakan, hasil penelitian Nur et al., (2010) pada dataran rendah < $400 \mathrm{~m} \mathrm{dpl}$ menunjukkan bahwa rata-rata jumlah anakan Selayar adalah 6,4 sedangkan Dewata 8,8. Jumlah anakan tersebut ternyata lebih banyak jika dibandingkan dengan yang dicapai dalam penelitian ini, yaitu rata-rata 5,23 untuk Selayar dan 4,0 untuk Dewata. Diduga hal ini disebabkan oleh tekanan suhu tinggi yang dialami oleh genotip yang ditanam di lokasi penelitian ini yaitu pada ketinggian 13 meter di atas permukaan laut relatif berat, sehingga lebih banyak asimilat yang direspirasikan menjadi energi dan lebih singkat siklus hidupnya, sehingga yang digunakan untuk mendukung perbanyakan anakan menjadi rendah. Dibawah kondisi kekeringan dan tekanan suhu tinggi maka siklus hidup tanaman gandum berlangsung lebih cepat dari pada dibawah kondisi normal, akibatnya lama stadia pertumbuhan tanaman menjadi lebih pendek, jumlah hari untuk 
akumulasi asimilat lebih sedikit sehingga produksi biomas menurun (Ghazi, 2012).

Umur berbunga dari duabelas genotip gandum yang diuji di lokasi ketinggian $13 \mathrm{~m}$ dpl, berkisar antara 65,67 hari hingga 71 hari, sedangkan umur panennya antara 95 hari hingga 99,67 hari. Hal ini berarti periode masa pengisian biji berlangsung sekitar 30 hari. Hasil penelitian Nur et al (2010) menunjukkan bahwa pada dataran rendah $<400$ m dpl, umur berbunga Selayar 66 hari, Dewata 64 hari, sedangkan umur panen Selayar 100 hari, Dewata 99 hari. Dari aspek umur berbunga dan umur panen, nampaknya panjang periode perkembangan tanaman ini tidak terlalu berbeda dibandingkan dengan yang ditanam pada ketinggian $>1000$ meter dpl (umur panennya rata-rata 108 hari) maka umur panen genotipe gandum yang diuji dalam penelitian ini rata-rata seminggu lebih cepat (Nur et al. 2010).

\section{Penampilan hasil tanaman dari dua belas genotipe gandum yang diuji}

Hasil analisis penampilan beberapa komponen hasil dari dua belas genotip gandum yang diuji di dataran rendah tropis, disajikan dalam Tabel 3.
Dari Tabel 3, terlihat bahwa bobot satu liter biji dari duabelas genotip gandum yang diuji tidak berbeda nyata, sedangkan parameter komponen hasil lainnya menunjukkan adanya variasi hasil terutama pada bobot biji dari 4 baris tengah yang dianggap mewakili hasil gandum per satuan luas. Dari komponen ini nampak bahwa genotip berkode B, F dan $\mathrm{H}$ lebih tinggi hasilnya dibandingkan berkode $\mathrm{J}$.

Wheeler et al (1996) menyebutkan bahwa lamanya pengisian biji gandum sangat ditentukan oleh suhu lingkungan dan semakin tinggi suhu udara maka semakin pendek periode pengisian bijinya. Akhir dari periode pengisian biji disebut sebagai fase kedewasaan massa biji. Laju (kecepatan) kedewasaan massa biji (waktu dari antesis atau mulainya pengisian biji ke fase kedewasaan masa biji) adalah suatu fungsi linier-positif dari suhu lingkungan. Dari pernyataan tersebut dapat dimengerti bahwa kaitannya dengan tekanan suhu tinggi pada umumnya menyebabkan periode pengisian biji menjadi lebih singkat. Di samping itu pada suhu lebih tinggi dari suhu optimumnya seringkali akumulasi asimilat menjadi kurang efisien, karena pada suhu tinggi tersebut laju

Tabel 3. Penampilan beberapa komponen hasil dari dua belas genotipe gandum yang diuji.

\begin{tabular}{ccccccccc}
\hline \multirow{2}{*}{$\begin{array}{c}\text { Kode } \\
\text { Genotipe }\end{array}$} & \multicolumn{7}{c}{$\begin{array}{c}\text { Bobot 1 liter } \\
\text { biji (gr) }\end{array}$} & \multicolumn{2}{c}{$\begin{array}{c}\text { Bobot 4 } \\
\text { Tengah }\end{array}$ (gr) } & \multicolumn{2}{c}{$\begin{array}{c}\text { Bobot 1000 } \\
\text { butir (gr) }\end{array}$} & \multicolumn{2}{c}{ jumlah biji/malai } \\
\hline A & 688,140 & A & 182,76 & BC & 29,77 & B & 27,57 & AB \\
B & 666,994 & A & 188,94 & C & 27,44 & AB & 27,17 & AB \\
C & 663,884 & A & 146,86 & ABC & 28,05 & AB & 30,03 & AB \\
D & 660,444 & A & 139,18 & ABC & 27,33 & AB & 31,27 & AB \\
E & 656,499 & A & 167,50 & ABC & 28,40 & AB & 35,47 & B \\
F & 685,591 & A & 206,29 & C & 28,55 & AB & 23,50 & A \\
G & 671,576 & A & 73,09 & AB & 27,12 & AB & 27,03 & AB \\
H & 706,351 & A & 200,61 & C & 26,40 & AB & 27,47 & AB \\
I & 696,494 & A & 176,90 & ABC & 30,22 & B & 30,07 & AB \\
J & 662,859 & A & 67,78 & A & 24,31 & A & 34,17 & B \\
K & 696,073 & A & 179,01 & ABC & 31,08 & B & 27,87 & AB \\
L & 682,076 & A & 138,19 & ABC & 27,73 & AB & 28,17 & AB \\
\hline
\end{tabular}

Keterangan: Angka yang diikuti oleh huruf yang sama menunjukkan tidak berbeda nyata antar perlakuan sedangkan angka yang diikuti huruf yang berbeda menunjukkan perbedaan yang nyata antar perlakuan. 
respirasi juga tinggi, artinya bahwa lebih banyak asimilat yang diubah menjadi energi.

Setiap penampilan dari komponen pertumbuhan maupun hasil tanaman gandum dalam penelitian ini, merupakan karakter penotip dari setiap genotipe yang diuji, sebagai hasil interaksi antara faktor genotip dengan faktor lingkungan dataran rendah pada ketinggian 13 meter dpl. Nilai ekonomi tanaman gandum terutama diukur dari hasil biji gandum per satuan luas, dan nilai ini sangat dipengaruhi oleh sejumlah komponen pertumbuhan maupun komponen hasil tanaman gandum. Untuk mengetahui keeratan masing-masing komponen tersebut dalam kaitannya dengan hasil per satuan luas, maka dianalisis menggunakan korelasi-regresi dan komponen yang mewakili hasil per satuan luas dalam penelitian ini adalah berat biji dari 4 baris tengah. Dari nilai keeratan hubungan itu kemudian dibuat skoring atau pembobotan dan hasilnya disajikan dalam Tabel 4.

Dalam Tabel 4, terlihat bahwa komponen jumlah malai per $\mathrm{m}^{2}$ dan jumlah anakan, nilai korelasinya paling mendekati 1,0 dibandingkan parameter lainnya, berarti hubungannya dengan bobot biji 4 baris tengah relatif lebih erat. Keeratan ini juga menunjukkan bahwa parameter tersebut lebih menentukan bobot biji 4 baris tengah yang dalam hal ini dianggap mewakili hasil gandum persatuan luas. Hal ini dapat dimengerti karena hasil biji gandum per satuan luas sangat tergantung pada jumlah malainya, sementara jumlah malai ini sangat ditentukan oleh jumlah anakan yang terbentuk.

Penampilan hasil yang paling baik dari duabelas genotip ini ditentukan oleh total skoring dari semua komponen pertumbuhan maupun komponen hasil yang diamati. Hasil total skoring dari dua belas genotip gandum yang diuji disajikan dalam Tabel 5.

Dari Tabel 5, terlihat bahwa skor akhir yang didapat bervariasi antara 103,08 hingga 108,40. Nilai skoring total yang relatif tinggi diperoleh dari genotip Menemen dan Basribey. Skoring yang diperoleh dari kedua genotip ini bahkan lebih tinggi dibandingkan genotip yang sudah dikenal masyarakat yaitu Dewata dan Selayar. Hasil pengujian tahap awal dari serangkaian proses seleksi untuk memperoleh tetua gandum adaptif dataran rendah ini menunjukkan bahwa penampilan genotip Menemen dan Barisbey lebih baik dibandingkan lainnya. Namun perlu diingat bahwa pengujian ini baru dilakukan sekali dan baru dalam satu lokasi, sehingga ada kemungkinan bahwa fenotip yang ditampilkan belum stabil. Masih

Tabel 4. Persentase Pembobotan Masing-masing Parameter Hasil Pengamatan

\begin{tabular}{clcc}
\hline No & \multicolumn{1}{c}{$\begin{array}{c}\text { Komponen / Parameter Hasil } \\
\text { Pengamatan }\end{array}$} & $\begin{array}{c}\text { Nilai } \\
\text { R terhadap } \\
\text { No.1 }\end{array}$ & $\begin{array}{c}\text { Persentase } \\
\text { Pembobotan }\end{array}$ \\
\hline 1 & Bobot 4 Baris Tengah & 1,000 & \\
2 & Bobot 1 liter biji & 0,2737 & 11,9 \\
3 & Bobot 1000 Butir & 0,3337 & 14,5 \\
4 & Jumlah Biji per Malai yang Berisi & 0,1792 & 7,8 \\
5 & Jumlah Malai per m2 & 0,5998 & 26,0 \\
6 & Tinggi Tanaman & 0,0019 & 0,1 \\
7 & Panjang Malai & 0,0884 & 3,8 \\
8 & Jumlah Anakan & 0,4012 & 17,4 \\
9 & Umur Berbunga & 0,221 & 9,6 \\
10 & Umur Panen & 0,2071 & 9,0 \\
\hline
\end{tabular}


diperlukan pengujian lapang beberapa kali pada tahun dan lokasi yang berbeda untuk menguji kestabilan respon genotip tersebut terhadap lingkungannya.

Secara umum hasil gandum dari dua belas genotip yang ditanam di dataran rendah ini masih sangat rendah jika dibandingkan dengan hasil gandum Dewata yang ditanam di dataran tinggi, yaitu mencapai 2,5 ton per ha. Ditinjau dari aspek pertumbuhannya, memang tinggi tanaman dan jumlah anakannya lebih rendah jika dibandingkan dengan penanaman di dataran tinggi. Tekanan karena suhu tinggi di lingkungan penanaman, ternyata menyebabkan pertumbuhan tanaman lebih rendah dan jumlah anakan menjadi lebih sedikit.

Beberapa referensi hasil penelitian berikut ini menunjukkan bahwa kepekaan setiap parameter pertumbuhan dan hasil tanaman gandum terhadap cekaman suhu tinggi dan keeratannya dalam menentukan hasil gandum cukup bervariasi. Asseng et al., (2010) menyebutkan bahwa dalam penelitian di lapang, tekanan oleh suhu tinggi sampai $40{ }^{\circ} \mathrm{C}$ selama 12 hari sebelum dan sesudah antesis mengakibatkan penurunan hasil biji gandum per $\mathrm{m}^{2}$ sebesar 50 persen. Sikder et al (2001) menyebutkan hasil penelitiannya pada tanaman gandum bahwa jumlah biji per spikelet, berat 1000 butir dan berat biji tanaman induk dapat digunakan untuk menentukan toleransi galur gandum yang toleran suhu tinggi. Shpiler dan Blum (1990) menyimpulkan hasil penelitiannya pada tanaman gandum bahwa jumlah biji per spikelet adalah penduga yang masuk akal kaitannya dengan toleransi terhadap tekanan suhu tinggi. Haque et al (2009) menyebutkan bahwa semakin besar thermostabilitas membran sel-nya maka akan semakin mendukung perubahan minimal dalam beberapa karakter fisiologis genotip gandum yang toleran suhu tinggi, sehingga hasil biji gandumnya tinggi. Dari beberapa referensi di atas dapat disimpulkan bahwa parameter jumlah biji per spikelet adalah parameter yang paling peka terhadap cekaman suhu tinggi.

Beberapa referensi hasil penelitian berikut ini menggambarkan bahwa cekaman suhu tinggi seringkali terjadi bersamaan dengan cekaman

Tabel 5. Tabel Hasil Analisis Skor Akhir

\begin{tabular}{cl}
\hline Skor & \multicolumn{1}{c}{ Genotipe } \\
\hline 103,08 & Alibey \\
& RABE/2*MO88 \\
& CMSS92Y01634T-18Y-010M- \\
& 010Y-010Y-1M-0Y-OHTY \\
103,32 & H-21 \\
103,43 & G-18 \\
104,02 & HP1744-01ND \\
104,10 & LAJ3302/2*MO88 \\
& CMSS92Y0164T-10Y-10M-10Y- \\
& 010Y-5M-0Y-OHTY \\
104,26 & G-21 \\
105,67 & Dewata \\
106,36 & OASIS/SKAUZ//4*BCN \\
& CMSS93Y04054M-1M-OY-OHTY \\
107,64 & Selayar \\
108,20 & Menemen \\
108,36 & Basribey \\
\hline
\end{tabular}


kekeringan. Hasil penelitian Prasad et al., (2011) menyebutkan bahwa pengaruh interaksi antara cekaman suhu tinggi dan kekeringan sangat nyata terhadap total bobot kering, indeks panen dan kesuburan spikelet tanaman gandum terutama pada cekaman suhu tinggi hingga $34^{\circ} \mathrm{C}$. Selama penelitian berlangsung, cekaman terhadap kekeringan sedikit dieliminasi dengan diberi pengairan agar tidak semua materi yang diuji mati. Dalam kondisi seperti itu, berarti bahwa baru cekaman suhu tinggilah yang lebih dominan dalam mempengaruhi penurunan hasil dari semua genotip yang diuji. Pengaruh kekeringan tidak menjadi salah satu cekaman yang sebenarnya secara alami akan muncul di lahan dataran rendah tadah hujan. Ghazi (2012) menyebutkan bahwa suhu udara di atas $28^{\circ} \mathrm{C}$ hingga $32^{\circ} \mathrm{C}$ untuk periode yang singkat ( 5 sampai 6 hari) ternyata menyebabkan kehilangan hasil gandum sekitar 20 persen. Dari hasil pengamatan selintas terhadap kondisi suhu udara selama penelitian, diduga faktor lingkungan ini sangat berpengaruh pada rendahnya penampilan hasil gandum dari dua belas genotip yang diuji.

\section{KESIMPULAN}

1. Penampilan pertumbuhan dan hasil tanaman dari dua belas genotip gandum yang ditanam di dataran rendah tropis dengan ketinggian 13 meter dpl bervariasi dalam hal tinggi tanaman, jumlah anak, bobot 1000 butir, jumlah biji per malai, bobot biji 4 baris tengah, tetapi tidak dalam hal umur berbunga, umur panen dan bobot 1 liter biji.

2. Berdasarkan hasil skor total setiap genotip, maka yang berpotensi untuk diuji kembali kemungkinannya menjadi calon tetua gandum dataran rendah tropis yaitu Basribey dan Menemen.

\section{DAFTAR PUSTAKA}

Asseng, S., Foster, I., Turner, N.C. 2010. The impact of temperature variability on wheat yields. Global Change Biology. Volume 17, Issue 2, 997-1012.

Das, S., Misra, R.C., Das, S.R., Pattnaik, M.C., Sinha, S.K. 2011. Integrated Analysis for Genotypic Adaptation In Rice. African Crop Science Journal, Vol. 19, No. 1, 15- 28.

Ghazi N. Al-Karaki. 2012. Phenological Development-Yield Relationships in Durum Wheat Cultivars under LateSeason High-Temperature Stress in a Semiarid Environment. ISRN Agronomy Volume 2012, 7 pages.

Gill, D.S. 2009. Agro-Physiological Traits For Screening Heat Tolerant Lines of Wheat (Triticum aestivum L.) Under Late Sown Conditions. Indian J. Agric. Res., 43 (3): 211-214.

Haque, M.Z., Hasan, MM., Rajib, M.M.R., Hasan, MM. 2009. Identification of cultivable heat tolerant wheat genotypes suitable for Patuakhali district in Bangladesh. J. Bangladesh Agril. Univ. 7(2): 241-246.

Nur, A., Trikoesoemaningtyas, Khumaida N dan Sujiprihati, S. 2010. Phenologi Pertumbuhan dan Produksi Gandum pada Lingkungan Tropika Basah. Prosiding Pekan Serealia Nasional, 2010.

Prasad, P. V. V., Pisipati, S.R., Momčilović, I., Ristic, Z. 2011. Independent and Combined Effects of High Temperature and Drought Stress During Grain Filling on Plant Yield and Chloroplast EF-Tu Expression in Spring Wheat. Journal of Agronomy and Crop Science Vol.197, Issue 6, 430-441.

Punia, S.S., A. Mansoor, A., Shah., B. Ramranwha, B. 2011. Genetic Analysis For High Temperature Tolerance in Bread Wheat. 
African Crop Science Journal, Vol. 19, No. 3,149-163.

Purchase, J.L., Hatting, H, and VanDevendra, C.S.2000. Genotype x environment interaction of winter wheat (Triticum aestivum L.) in South Africa: Stability analysis of yield performance. Sout Africa Journal of Plant soil 17:101-107.

Rossi, V., Ravanetti, A., Pattori, E., Giosue, S., 2001. Influence of Temperature and Humidity on The Infection of Wheat Spikes by Some Fungi Causing Fusarium Head Blight. Journal of Plant Pathology, 83 (3), 189-198.

Shpiler, L dan Blum, A. 1990. Heat Tolerance for Yield and Its Components in Different Wheat Cultivars. Euphytica, Vol.51. No.3: 257-263.
Sikder, S., Ahmed, J.U., Hossain, T. 2001. Heat Tolerance and Relative Yield Performance of Wheaat Varieties Under Late Seeded Conditions. Indian J. Agric. Res. 35 (3): 141-148.

Tentrirawe, A dan Pabbage, M.S. 2010. Pembentukan Calon Varietas Gandum Tahan Hama Pada Ketinggian 300-400 Meter dpl. Balai Penelitian Tanaman Serealia Maros.

Wheeler, T.R., Hong, T.D., Ellis R.H., Batts G.R., Morison J.I.L. and Hadley, P. 1996. The duration and rate of grain growth, and harvest index, of wheat [Triticum aestivum L.) in response to temperature and $\mathrm{CO2}$. Journal of Experimental Botany, Vol. 47, No. 298, 623-630. 